\title{
The effect of varied training for developing some special physical abilities on the effectiveness of composite offensive performances among Kumite youth female players
}

\section{*Dr/ Omaima Kamal Hassan Ali}

Introduction:

Physical Preparation is an important aspect of the technical performance in Karate, as the players' ability to perform the requirements and duties of performance, both offensive and defensive, in training and contests is based on it. Improving the technical level requires developing structured training programs in accordance with the latest developments of the produced tactics; offensive, defensive and counter attack techniques; and the latest amendments in Karate rules. Weight and plyometric exercises are important for most individual sports as they are effective in developing the physical abilities of individual sports female players.

Weight training and plyometric training have advantages and drawbacks. However, using diverse sets of methods, approaches, and exercises by combining advantages of both approaches (weight training and plyometrics) can lead to better results in developing the physical and skills level of athletes, which is called the varied training (47: 79; 55: 540; 51: 64)

Varied training aims at avoiding the constant course of training that is limited to using the regular training method by changing this approach by using light and heavy weights successively while working on having an explosive performance in both cases. The variation can be reached by alternating the loads (maximum power, strength endurance, speed-strength) in an explosive way, by changing the load level, changing the type of muscle contraction and tension, or moving from weight training to plyometrics (Abdel Maqsoud, 1998: 317319).

"Karate instructor, Department of Water and Combat Sports, Faculty of Physical Education for Girls, Zagazig University. 
Karate consists of two types of contests: first is the mock fight contest (Kata), which is a set of defensive and offensive Karate skills which experts put in a series of coordinated moves to be performed by the player in different directions through which the player's performance level can be adjudicated; and second is the actual fight contest (Kumite) which is a combat of a particular duration between two equivalent players (belt), weight, age group, and gender where each player uses their limbs (arms and legs) to suppress the other's attempts to score points in the areas permissible areas for offense and scoring within the Karate rules and regulations (Ibrahim \& Al-Bisaty, 1995: 28).

Mahmoud Rabie (2005) states that the actual fight (Kumite) is "the optimal utilization of the player's capacities and potential against their opponent either by defense or offense within the determined duration of the match and within the framework of the Karate rules which are agreed upon on the international level, in order to attain the best achievement level." He adds that the Kumite provides the player with selfconfidence, courage, initiative, good conduct in rapidly changing situations, and selfdefense and fight against others (Al-Beshihy, 2005: 11).

Wagih Shamady (2002) notes that in order for the player to execute the offensive performance in a balanced manner, they have to connect the elements of offense at high speed, move the body positions on the sides quickly to avoid the opponent's reaction, therefore the player should be trained on the offensive set with an emphasis on each move with accuracy and a sufficient distance so that they are trained in a streamline manner and free sequence (Shamandy, 2002: 101).

Mosaad Mahmoud (1997) notes that the wrestler who is proficient in the composite motor skills perplexes his opponents, surprises him with an unexpected skill, and the combat ends in his favor in most cases. Additionally the composite motor skill contributes to the development of neuromuscular coordination, agility, and balance, as well as improvement of techniques (Mahmoud, 1997: 271).

Sherif Al-Awady (1989) points out that when the Karate player uses offensive waves, they acquire greater skills 
abilities especially when using them in axes of different directions around the opponent (Al-Awady, 1989: 15).

Kobayashi and Sharp (1997) also add that the importance of the composite offensive skills and their effectiveness in achieving a win with minimal effort emerge in matches, namely for the one who has greater composite offensive skills, ability to employ and use them appropriately in the right time (Kobayashi \& Sharp, 1997: 100).

Mahmoud Amer's study (2013) found a deficit in and ineffectiveness of the performance of offensive combinations in matches, as most players focused on individual skills. Amer reached these findings by analyzing a national Karate championship. $\mathrm{He}$ also found that:

The number of successful individual trails was 175 , about $71.90 \%$ of the overall skills.

- The number of successful offensive combinations was 35 , about $13.67 \%$ of the overall skills (Metwally, 2013: 103, 108).

The researcher also notes that coaches and researchers who used weight and plyometric training in their programs and studies have done so separately, as their used them in turn within the training modules, or they used weight training to build a power basis that enables them to use ploymetric exercises later or during the general preparation period. However, none has used both in the varied approach.

From

the aforementioned, the researcher sought to identify the effect of using the varied training (weight training - plyometric training) in developing some special physical abilities and the effectiveness of composite offensive performances of Kumite female youth players in Karate.

\section{Research Objectives:}

This research aims to develop a training program using the varied training approach (weight training - plyometric training) with Kumite female youth players below 14 years of age and identifying its effects on:

1. The special physical abilities (muscular ability of the arms and legs, pelvic flexibility, agility, punching speed, kicking speed) among Kumite female youth players below 14 year of age.

2. The effectiveness of composite offensive performances under research 
among Kumite female youth players below 14 years of age.

\section{Research Hypotheses:}

1. There are statistically significant differences between the means of the experimental group's pre-test and post-test measurements in some special physical abilities and the effectiveness of Kumite composite offensive performances under research in favor of the post-test measurement.

2. There are statistically significant differences between the means of the control group's pre-test and post-test measurements in some special physical abilities and the effectiveness of Kumite composite offensive performances under research in favor of the post-test measurement.

3. There are statistically significant differences between the means of the post-test measurements of the experimental and control groups in some special physical abilities and the effectiveness of Kumite composite offensive performances under research in favor of the experimental group.

\section{Research Procedures: Research Method:}

The researcher applied the experimental method as it is the most appropriate method for this research, using a twogroup (an experimental group and a control group) experimental design with a pretest/post-test measurements.

Research Sample:

The research sample was purposively selected from Kumite female youth players below 14 years of age in the Karate sport in the Golf Club, and the Suez Canal Club in Ismailia, who are registered with the Egyptian Karate Federation during the training season 2016/2017, and who are holders of the black belt $\left(1^{\text {st }}\right.$ Dan) and brown belt $\left(1^{\text {st }}\right)$ at least. The sample consisted of 40 female youth players. Ten players from the same research populations and not included in the research core sample were assigned to the exploratory sample. Thus, the research core sample consisted of 30 players assigned to two groups: an experimental group and a control group, each consisted of 15 players.

Equivalence of the two research groups:

The researcher calculated the equivalence of the two groups (experimental and control groups) in the variables under research. 
Table (1)

Significance of differences between the experimental group and control group in growth rates (age, height, weight, and period of training)

\begin{tabular}{l|c|c|c|c|c|c}
\hline \multirow{2}{*}{ Variables } & \multirow{2}{*}{$\begin{array}{c}\text { Measurement } \\
\text { Unit }\end{array}$} & \multicolumn{2}{|c|}{$\begin{array}{c}\text { Experimental } \\
\text { group N = 15 }\end{array}$} & \multicolumn{2}{|c|}{$\begin{array}{c}\text { Control } \\
\text { group N = 15 }\end{array}$} & \multirow{2}{*}{$\begin{array}{c}\boldsymbol{t} \\
\text { value }\end{array}$} \\
\cline { 3 - 6 } & & $\mathbf{M}$ & SD & M & SD & \\
\hline \hline Age & Year & 12.81 & 0.51 & 12.90 & 0.49 & 0.48 \\
\hline Height & $\mathrm{Cm}$ & 149.13 & 4.99 & 149.65 & 5.27 & 0.27 \\
\hline Weight & $\mathrm{Kg}$ & 46.00 & 3.73 & 46.44 & 4.21 & 0.29 \\
\hline Period of training & Year & 4.15 & 0.59 & 4.30 & 0.66 & 0.63 \\
\hline \hline
\end{tabular}

Tabular $t$ value at $p$ level $0.05=2.048$

Table 1 shows that there weight, and period of training) are no significant differences between the experimental group and the control group in growth rates (age, height,

\section{Table (2)}

Significance of differences between the experimental group and control group in the special physical abilities under research

\begin{tabular}{l|c|c|c|c|c|c}
\hline \hline Variables & $\begin{array}{c}\text { Measurement } \\
\text { Unit }\end{array}$ & \multicolumn{2}{|c|}{$\begin{array}{c}\text { Experimental } \\
\text { group N 15 }\end{array}$} & \multicolumn{2}{|c|}{$\begin{array}{c}\text { Control } \\
\text { group N = 15 }\end{array}$} & \multirow{2}{*}{$\begin{array}{c}\boldsymbol{t} \\
\text { value }\end{array}$} \\
\cline { 3 - 7 } & & $\mathrm{M}$ & $\mathrm{SD}$ & $\mathrm{M}$ & $\mathrm{SD}$ & \\
\hline \hline $\begin{array}{l}\text { Arms muscular } \\
\text { ability }\end{array}$ & $\mathrm{M}$ & 2.79 & 0.58 & 2.85 & 0.63 & 0.26 \\
\hline $\begin{array}{l}\text { Legs muscular } \\
\text { ability }\end{array}$ & $\mathrm{Cm}$ & 145.00 & 10.13 & 145.50 & 10.57 & 0.13 \\
\hline $\begin{array}{l}\text { Pelvic } \\
\text { flexibility }\end{array}$ & $\mathrm{Cm}$ & 18.59 & 4.48 & 18.17 & 4.89 & 0.24 \\
\hline Agility & Repetitions & 7.50 & 1.73 & 7.88 & 1.96 & 0.54 \\
\hline Punching speed & Repetitions & 5.36 & 1.25 & 5.72 & 1.41 & 0.72 \\
\hline Kicking speed & Repetitions & 4.50 & 1.19 & 4.60 & 1.22 & 0.37 \\
\hline \hline
\end{tabular}

Tabular $t$ value at $p$ level $0.05=2.048$

Table 2 demonstrates that there are no significant differences at $p$ level 0.05

between the experimental and control groups in the special physical abilities under 
research, indicating the groups in these variables. equivalence of the research

Table (3)

Significance of differences between the experimental group and control group in the performance of some composite offensive performances under research

\begin{tabular}{l|c|c|c|c|c|c}
\hline \hline Variables & $\begin{array}{c}\text { Measurement } \\
\text { Unit }\end{array}$ & \multicolumn{2}{|c|}{$\begin{array}{c}\text { Experimental } \\
\text { group } \\
\mathbf{N = 1 5}\end{array}$} & \multicolumn{2}{|c|}{$\begin{array}{c}\text { Control } \\
\text { group } \\
\text { N= 15 }\end{array}$} & $\begin{array}{c}t \\
\text { value }\end{array}$ \\
\cline { 3 - 6 } & & $\mathrm{M}$ & $\mathrm{SD}$ & $\mathrm{M}$ & $\mathrm{SD}$ & \\
\hline \hline $\begin{array}{l}\text { Kizami Zuki- } \\
\text { Gyaku Zuki }\end{array}$ & Repetitions & 5.59 & 0.97 & 5.67 & 0.99 & 0.22 \\
\hline $\begin{array}{l}\text { Kizami Zuki- } \\
\text { Kizami Mawashi } \\
\text { Geri }\end{array}$ & Repetitions & 5.37 & 0.91 & 5.41 & 0.95 & 0.12 \\
\hline $\begin{array}{l}\text { Kizami Zuki- } \\
\text { Gyaku Zuki- } \\
\text { Kizami Mawashi } \\
\text { Geri }\end{array}$ & Repetitions & 5.03 & 0.93 & 5.15 & 0.98 & 0.33 \\
$\begin{array}{l}\text { Gyaku Zuki- } \\
\text { Kizami Mawashi } \\
\text { Geri }\end{array}$ & Repetitions & 5.25 & 0.96 & 5.31 & 0.91 & 0.17 \\
\hline $\begin{array}{l}\text { Kizami Zuki- } \\
\text { Gyaku Zuki- } \\
\text { Kizami Ura } \\
\text { Mawashi Geri }\end{array}$ & Repetitions & 4.83 & 0.89 & 4.91 & 0.85 & 0.24 \\
\hline \hline
\end{tabular}

Tabular $t$ value at $p$ level $0.05=2.048$

Table (3) shows that there are no statistically significant differences at $\mathrm{p}$ level 0.05 between the experimental group and the control group in the effective performance of some composite offensive performances under research,

indicating the equivalence of the two groups.

Evaluating the effectiveness of the composite offensive performances under research:

The effectiveness of the composite offensive performances under research was measured through the player's participation in six 
matches having a specific offensive duty (the composite offensive performances) against players of the same age group and weight from another club. The match duration was two minutes whereby each player executed the 10 trials of the composite offensive performance during the match in order to identify the number of successful composite offensive performances by each player participating in the research. A refereeing panel from the Egyptian Karate Federation ran the matches.

The Research Tools and Devices:

1- A restameter device to measure height in centimeters and weight in kilograms

2- Weight devices, boxing gloves pads, head and hand guards, cones

3- Wooden boxes, hurdles in different heights

4- Dumbbells, medicine balls in different weights $(2 \mathrm{~kg}, 3 \mathrm{~kg})$

5-25-meter measuring tape

6- $100-\mathrm{cm}$ graduated ruler

7- Stopwatch

The proposed varied training program:

A. Purpose of the proposed training program:
1. To develop some special physical abilities among Kumite female youth players below 14 years of age.

2. To improve the effectiveness of the composite offensive performances among Kumite female youth players below 14 years of age.

B. Contents of the training program:

The content of the varied training program (weight training and plyometrics) was determined after reviewing many references and studies specialized in resistance training (Abdullah, 2010; AlSokary \& Breiqa, 2001; Tantawy \& Abdul Qader, 2004; Said, Mohamed, \& Hassan, 2010; Zayed, 2000; Al-Sayed, 2004; Mohamed, 2015; Abdul Hay, 2015; AlSafy, 2009; Jamal, 2013), and conducting the exploratory study. The researcher concluded a set of weight and plyometric exercises, submitted them to experts in Karate (attachment 4) in order to identify the most suitable exercises for the level of the research core sample. The following exercises were selected:

a. Weight exercises: 
1. (Lying on a high bench, arms bent, grip the device's handle) extend the arms to the front.

2. (Standing, underhand grip, arms are bent to the back) extend arms up.

3. (Kneeling, arms up, grip device's handle) pull the bar down.

4. (Standing, holding the bar in front of the chest) extend arms up.

5. (Squat position) extend the knees.

6. (Straight arm plank position, device behind ankles) bend knees.

7. (Sitting on a high bench, device on the insteps) extend the knees.

8. (Lying, knees bent) bend the torso forward.

b. Plyometric exercises (attachment 5):

1. Deep jump

2. Deep jump with a leap

3. Quick leap jump

4. Chest pass with a medicine ball

5. Throwing a medicine ball from a twisted position on each side.

6. Dumbbell curls

7. Vertical curls

8. Horizontal curls

\section{Varied \\ Training}

\section{Program Timeline:}

Following the experts' opinions and the findings of related previous studies, the researcher divided the program to 24 training modules over a period of eight weeks, so that three training modules are offered per week. The duration of each training module is 70 minutes, then the player continues for 30 more minutes with the skills training.

D. Parts of the daily training modules:

a. Physical conditioning (15 minutes):

This part is performed by the participants in the experimental and control groups to condition the respiratory and circulatory systems, with a focus on stretching and flexibility exercises.

b. Main part (50 minutes):

This part contained four weight and plyometric exercises. In this part, participants are divided into the experimental group, which performs weight and plyometric exercises, and the control group, which performs the traditional training, in addition to a 30minute skills training on the Kumite composite offensive 
performances by the members of the two groups.

c. Final part (5 minutes):

This part is performed by participants in the experimental and control groups, and it includes relaxation, cool-down, and light stretching exercises.

The researcher points out that the contents of the training program using the varied training approach is shown

\section{Results and Discussion:}

\section{Table (4)}

Significance of differences between the experimental group's pretest and post-test measurements in the studied special physical abilities $\mathrm{N}=15$

\begin{tabular}{|c|c|c|c|c|c|c|c|}
\hline \multirow[t]{2}{*}{ Variables } & \multirow[t]{2}{*}{$\begin{array}{c}\text { Measurement } \\
\text { Unit }\end{array}$} & \multicolumn{2}{|c|}{$\begin{array}{l}\text { Pre-test } \\
\text { measurement }\end{array}$} & \multicolumn{2}{|c|}{$\begin{array}{l}\text { Post-test } \\
\text { measurement }\end{array}$} & \multirow[t]{2}{*}{$\begin{array}{l}t \boldsymbol{t} \\
\text { value }\end{array}$} & \multirow[t]{2}{*}{$\begin{array}{l}\text { Improvement } \\
\text { rate }\end{array}$} \\
\hline & & $\mathbf{M}$ & SD & $\mathbf{M}$ & SD & & \\
\hline $\begin{array}{l}\text { Arms } \\
\text { muscular } \\
\text { ability }\end{array}$ & $\bar{M}$ & 2.79 & 0.58 & 3.25 & 0.24 & $4.17 *$ & $16.49 \%$ \\
\hline $\begin{array}{l}\text { Legs } \\
\text { muscular } \\
\text { ability }\end{array}$ & $\mathrm{Cm}$ & 145.00 & 10.13 & 160.55 & 5.95 & $3.92 *$ & $10.72 \%$ \\
\hline $\begin{array}{l}\text { Pelvic } \\
\text { flexibility }\end{array}$ & $\mathrm{Cm}$ & 18.59 & 4.48 & 11.31 & 2.76 & $5.28^{*}$ & $64.37 \%$ \\
\hline Agility & Repetitions & 7.50 & 1.73 & 11.91 & 1.29 & $5.33^{*}$ & $58.80 \%$ \\
\hline $\begin{array}{l}\text { Punching } \\
\text { speed }\end{array}$ & Repetitions & 5.36 & 1.25 & 8.00 & 1.11 & $4.97 *$ & $49.25 \%$ \\
\hline $\begin{array}{l}\text { Kicking } \\
\text { speed }\end{array}$ & Repetitions & 4.50 & 1.19 & 7.21 & 0.93 & $5.12 *$ & $60.22 \%$ \\
\hline
\end{tabular}

Tabular $t$ value at $p$ level $0.05=2.145$

* significant at $p$ level 0.05

Table 4 demonstrates the statistically significant differences between the experimental group's pre-test and post-test measurements at $\mathrm{p}$ level 0.05 in the special physical variables (arms

muscular ability, legs muscular ability, flexibility, agility, performance speed) in favor of the post-test measurement. The improvement rates ranged between $10.72 \%$ and $64.37 \%$.

Table (5)

Assiut Journal For Sport Science Arts 
Significance of differences between the experimental group's pretest and post-test measurement in the studied composite offensive performances $(\mathrm{N}=15)$

\begin{tabular}{|c|c|c|c|c|c|c|c|}
\hline \multirow[t]{2}{*}{ Variables } & \multirow[t]{2}{*}{$\begin{array}{c}\text { Measurement } \\
\text { Unit }\end{array}$} & \multicolumn{2}{|c|}{$\begin{array}{c}\text { Pre-test } \\
\text { measurement }\end{array}$} & \multicolumn{2}{|c|}{$\begin{array}{c}\text { Post-test } \\
\text { measurement }\end{array}$} & \multirow[t]{2}{*}{$\begin{array}{c}t \\
\text { value }\end{array}$} & \multirow[t]{2}{*}{$\begin{array}{l}\text { Improvement } \\
\text { rates }\end{array}$} \\
\hline & & $\mathrm{M}$ & SD & $\mathrm{M}$ & SD & & \\
\hline $\begin{array}{l}\text { Kizami } \\
\text { Zuki- } \\
\text { Gyaku } \\
\text { Zuki }\end{array}$ & Repetitions & 5.59 & 0.97 & 8.47 & 0.88 & $4.91 *$ & $51.52 \%$ \\
\hline $\begin{array}{l}\text { Kizami } \\
\text { Zuki- } \\
\text { Kizami } \\
\text { Mawashi } \\
\text { Geri }\end{array}$ & Repetitions & 5.37 & 0.91 & 8.00 & 0.79 & $4.36^{*}$ & $48.98 \%$ \\
\hline $\begin{array}{l}\text { Kizami } \\
\text { Zuki- } \\
\text { Gyaku } \\
\text { Zuki- } \\
\text { Kizami } \\
\text { Mawashi } \\
\text { Geri }\end{array}$ & Repetitions & 5.03 & 0.93 & 7.85 & 0.81 & $5.12 *$ & $56.06 \%$ \\
\hline $\begin{array}{l}\text { Gyaku } \\
\text { Zuki- } \\
\text { Kizami } \\
\text { Mawashi } \\
\text { Geri }\end{array}$ & Repetitions & 5.25 & 0.96 & 8.19 & 0.84 & $4.79 *$ & $56.00 \%$ \\
\hline $\begin{array}{l}\text { Kizami } \\
\text { Zuki- } \\
\text { Gyaku } \\
\text { Zuki- } \\
\text { Kizami } \\
\text { Ura } \\
\text { Mawashi } \\
\text { Geri }\end{array}$ & Repetitions & 4.83 & 0.89 & 7.25 & 0.71 & $5.23 *$ & $50.10 \%$ \\
\hline
\end{tabular}

Tabular $t$ value at $p$ level $0.05=2.145 *$ significant at $p$ level 0.05

Table 5 shows that there are significant differences at $\mathrm{p}$ level 0.05 between the experimental group's pre-test and post-test measurements in the effectiveness of some composite offensive performances under research in favor of the post-test measurement. 
improvement rates ranged between $48.98 \%$ and $56.06 \%$.

The researcher attributes the improvement in the level of special physical abilities and the effectiveness of some composite offensive performances to the effectiveness of the proposed varied training program which was applied to the experimental group. The proposed program contained a set of weight and plyometric exercises, which resembled in their nature the composite offensive performances during matches, and which had a positive effect on the level of the special physical abilities as these exercises were the only different variable that was added to the program applied to the experimental and control groups. Thus, it is important to incorporate exercises related to the nature of Kumite composite offensive performances in the training program of Kumite female players.

This

finding is consistent with Hassanein and Kesra's remark (1998) that developing the athletes' special physical abilities is important as it is the basic foundation of physical performance and sports practice. Resistance exercises is one of the primary forms of exercises that develop muscular ability, agility and performance speed.

It is also consisted with the findings of other studies (Zayed, 2000; Abul Nour, 2002; Al-Shabrawy \& Abdul Qader, 2004; Al-Sayed, 2004; Al-Ghamrawy, 2007; Gregory, 2007; Al-Safy, 2009; Abdullah, 2010; Said, et al., 2011; Jamal, 2013; Mohamed, 2015; and Abdul Hay, 2015) that resistance exercises and varied exercises are effective in developing athletes' special physical abilities and the skills performance.

In this regard, De Sants (1995) noted that when players had the special physical abilities in any sport activity, it helped them reduce the time required for acquiring and mastering the motor skills. Also, the development of the players' technical performance depended on how well developed their physical abilities are. Moreover, the physical abilities are the basic foundation for improving the level of athletes' technical performance.

Abd El-Maqsoud (1997) added that mastering motor 
skills would not be attained without the full development of physical abilities because the performance level improves in association with special physical abilities. Furthermore, there is a correlation between physical abilities and motor skills, which constitute an essential foundation for acquiring motor skills. Accordingly, this mutual relationship between the two variables demonstrates the level of their interdependence. Saleh (2001) pointed out that resistance exercises contributed to a great extent and effectively in the development of motor

Table (6)

Significance of differences between the control group's pre-test and post-test measurements in the studied special physical abilities $\mathrm{N}=15$

\begin{tabular}{|c|c|c|c|c|c|c|c|}
\hline \multirow[t]{2}{*}{ Variables } & \multirow[t]{2}{*}{$\begin{array}{c}\text { Measurement } \\
\text { Unit }\end{array}$} & \multicolumn{2}{|c|}{$\begin{array}{c}\text { Pre-test } \\
\text { measurement }\end{array}$} & \multicolumn{2}{|c|}{$\begin{array}{c}\text { Post-test } \\
\text { measurement }\end{array}$} & \multirow[t]{2}{*}{$\begin{array}{c}t \\
\text { value }\end{array}$} & \multirow[t]{2}{*}{$\begin{array}{c}\text { Improvement } \\
\text { rate }\end{array}$} \\
\hline & & M & SD & M & SD & & \\
\hline $\begin{array}{l}\text { Arms } \\
\text { muscular } \\
\text { ability }\end{array}$ & M & 2.85 & 0.63 & 3.05 & 0.26 & $2.29 *$ & $7.02 \%$ \\
\hline $\begin{array}{l}\text { Legs } \\
\text { muscular } \\
\text { ability }\end{array}$ & $\mathrm{Cm}$ & 145.50 & 10.57 & 155.00 & 5.50 & $2.41 *$ & $6.53 \%$ \\
\hline $\begin{array}{l}\text { Pelvic } \\
\text { flexibility }\end{array}$ & $\mathrm{Cm}$ & 18.17 & 4.89 & 15.19 & 3.11 & $2.21 *$ & $19.62 \%$ \\
\hline Agility & Repetitions & 7.88 & 1.96 & 9.65 & 1.38 & $2.32 *$ & $22.46 \%$ \\
\hline $\begin{array}{l}\text { Punching } \\
\text { speed }\end{array}$ & Repetitions & 5.72 & 1.41 & 6.64 & 1.29 & $2.18^{*}$ & $16.08 \%$ \\
\hline $\begin{array}{l}\text { Kicking } \\
\text { speed }\end{array}$ & Repetitions & 4.60 & 1.22 & 6.29 & 0.91 & $2.25^{*}$ & $36.74 \%$ \\
\hline
\end{tabular}

Tabular $t$ value at $p$ level $0.05=2.145$ Assiut Journal For Sport Science Arts skills in Karate. It is also important to use a variety of tools during Karate training while taking into account the required intensity. Quinn (1988), and Nashayama and Richard (1990) also agreed that developing the physical qualifications is essential for developing the skills performance in Karate, especially punching and kicking, thus improving the level of performing the skills during matches.

Thus, the first hypothesis is supported. 
Table 6 shows that there are significant differences at $p$ level 0.05 between the control group's pre-test and post-test measurements in the studied special physical abilities in favor of the post-test measurement. The improvement rates ranged between $6.53 \%$ and $36.74 \%$.

\section{Table (7)}

Significance of differences between the control group's pre-test and post-test measurement in the studied composite offensive performances $N=15$

\begin{tabular}{|c|c|c|c|c|c|c|c|}
\hline \multirow[t]{2}{*}{ Variables } & \multirow[t]{2}{*}{$\begin{array}{l}\text { Measurement } \\
\text { Unit }\end{array}$} & \multicolumn{2}{|c|}{$\begin{array}{l}\text { Pre-test } \\
\text { measurement }\end{array}$} & \multicolumn{2}{|c|}{$\begin{array}{l}\text { Post-test } \\
\text { measurement }\end{array}$} & \multirow[t]{2}{*}{$\begin{array}{l}t \\
\text { value }\end{array}$} & \multirow[t]{2}{*}{$\begin{array}{l}\text { Improvement } \\
\text { rates }\end{array}$} \\
\hline & & $\mathrm{M}$ & SD & $\mathrm{M}$ & $\mathrm{SD}$ & & \\
\hline $\begin{array}{l}\text { Kizami } \\
\text { Zuki- } \\
\text { Gyaku } \\
\text { Zuki }\end{array}$ & Repetitions & 5.67 & 0.99 & 7.71 & 0.91 & $2.85^{*}$ & $35.98 \%$ \\
\hline $\begin{array}{l}\text { Kizami } \\
\text { Zuki- } \\
\text { Kizami } \\
\text { Mawashi } \\
\text { Geri }\end{array}$ & Repetitions & 5.41 & 0.95 & 7.25 & 0.83 & $2.91 *$ & $34.01 \%$ \\
\hline $\begin{array}{l}\text { Kizami } \\
\text { Zuki- } \\
\text { Gyaku } \\
\text { Zuki- } \\
\text { Kizami } \\
\text { Mawashi } \\
\text { Geri }\end{array}$ & Repetitions & 5.15 & 0.98 & 7.00 & 0.87 & $3.14 *$ & $35.92 \%$ \\
\hline $\begin{array}{l}\text { Gyaku } \\
\text { Zuki- } \\
\text { Kizami } \\
\text { Mawashi } \\
\text { Geri }\end{array}$ & Repetitions & 5.31 & 0.91 & 7.11 & 0.82 & $3.02 *$ & $33.89 \%$ \\
\hline $\begin{array}{l}\text { Kizami } \\
\text { Zuki- } \\
\text { Gyaku } \\
\text { Zuki- } \\
\text { Kizami } \\
\text { Ura } \\
\text { Mawashi } \\
\text { Geri }\end{array}$ & Repetitions & 4.91 & 0.85 & 6.63 & 0.77 & $2.94 *$ & $35.03 \%$ \\
\hline
\end{tabular}

Tabular $t$ value at $p$ level $0.05=2.145$

* significant at $p$ level 0.05 
Table 7 shows that there are significant differences at $p$ level 0.05 between the control group's pre-test and post-test measurements in the effectiveness of some composite offensive performances under research in favor of the post-test measurement.

The improvement rates ranged between $33.89 \%$ and $35.98 \%$.

The researcher attributes this positive impact to the traditional training program and the full-body physical exercises and skills exercises related to the composite offensive performances it contained, in addition to the control group members' regular participation in and continuation of training which had a positive effect on the studied special physical abilities and the effectiveness of some composite offensive performances.

The researcher also attributes this improvement in the control group's performance to the fact that the duration of application was adequate for developing the special physical abilities. This finding is consistent with Beachle and Earle's (2000) remark that developing the physical abilities requires a 68-week period at least with 3-5 training modules per week (Beachle \& Earle, 2000: 435). Thus, the second hypothesis is supported.

\section{Table 8}

Significance of differences between the post-test measurements of the experimental and control group in the studied special physical abilities

\begin{tabular}{l|l|l|l|l|l|c}
\hline \hline \multicolumn{1}{c|}{ Variables } & \multirow{2}{*}{$\begin{array}{c}\text { Measurement } \\
\text { Unit }\end{array}$} & \multicolumn{2}{|c|}{$\begin{array}{c}\text { Experimental } \\
\text { group N 15 }\end{array}$} & \multicolumn{2}{c|}{$\begin{array}{c}\text { Control } \\
\text { Group N 15 }\end{array}$} & $\begin{array}{c}t \\
\text { value }\end{array}$ \\
\cline { 3 - 6 } & & $\mathrm{M}$ & $\mathrm{SD}$ & $\mathrm{M}$ & $\mathrm{SD}$ & \\
\hline \hline $\begin{array}{l}\text { Arms muscular } \\
\text { ability }\end{array}$ & $\mathrm{M}$ & 3.25 & 0.24 & 3.05 & 0.26 & $2.11^{*}$ \\
\hline $\begin{array}{l}\text { Legs } \\
\text { ability }\end{array}$ & $\mathrm{Cm}$ & 160.55 & 5.95 & 155.00 & 5.50 & $2.56^{*}$ \\
\hline Pelvic flexibility & $\mathrm{Cm}$ & 11.31 & 2.76 & 15.19 & 3.11 & $3.49^{*}$ \\
\hline Agility & Repetitions & 11.91 & 1.29 & 9.65 & 1.38 & $4.48^{*}$ \\
\hline Punching speed & Repetitions & 8.00 & 1.11 & 6.64 & 1.29 & $2.99^{*}$ \\
\hline Kicking speed & Repetitions & 7.21 & 0.93 & 6.19 & 0.90 & $2.93^{*}$ \\
\hline \hline
\end{tabular}

Tabular $t$ value at $p$ level $0.05=2.048 \quad *$ significant at $p$ level 0.05 
Table 8 indicates that there are statistically significant differences at $p$ level 0.05 between the post-test measurements of the experimental group and the control group in the studied special physical abilities in favor of the experimental group.

Table (9)

Significance of differences between the post-test measurement in the studied composite offensive performances

\begin{tabular}{|c|c|c|c|c|c|c|}
\hline \multirow[t]{2}{*}{ Variables } & \multirow[t]{2}{*}{$\begin{array}{c}\text { Measurement } \\
\text { Unit }\end{array}$} & \multicolumn{2}{|c|}{$\begin{array}{c}\text { Experimental } \\
\text { group } N=15\end{array}$} & \multicolumn{2}{|c|}{$\begin{array}{c}\text { Control } \\
\text { groupN=15 }\end{array}$} & \multirow[t]{2}{*}{$\begin{array}{c}t \\
\text { value }\end{array}$} \\
\hline & & $\mathrm{M}$ & SD & $\mathrm{M}$ & SD & \\
\hline $\begin{array}{l}\text { Kizami Zuki- } \\
\text { Gyaku Zuki }\end{array}$ & Repetitions & 8.47 & 0.88 & 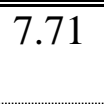 & 0.91 & $2.25 *$ \\
\hline $\begin{array}{l}\text { Kizami Zuki- } \\
\text { Kizami } \\
\text { Mawashi Geri }\end{array}$ & Repetitions & 8.00 & 0.79 & 7.25 & 0.83 & $2.46^{*}$ \\
\hline $\begin{array}{l}\text { Kizami Zuki- } \\
\text { Gyaku Zuki- } \\
\text { Kizami } \\
\text { Mawashi Geri }\end{array}$ & Repetitions & 7.85 & 0.81 & 7.00 & 0.87 & $2.67 *$ \\
\hline $\begin{array}{l}\text { Gyaku Zuki- } \\
\text { Kizami } \\
\text { Mawashi Geri }\end{array}$ & Repetitions & 8.19 & 0.84 & 7.11 & 0.82 & $3.44^{*}$ \\
\hline $\begin{array}{lr}\text { Kizami } & \text { Zuki- } \\
\text { Gyaku } & \text { Zuki- } \\
\text { Kizami Ura } & \text { Ura } \\
\text { Mawashi Geri }\end{array}$ & Repetitions & 7.25 & 0.71 & 6.63 & 0.77 & $2.23 *$ \\
\hline \multicolumn{7}{|c|}{ 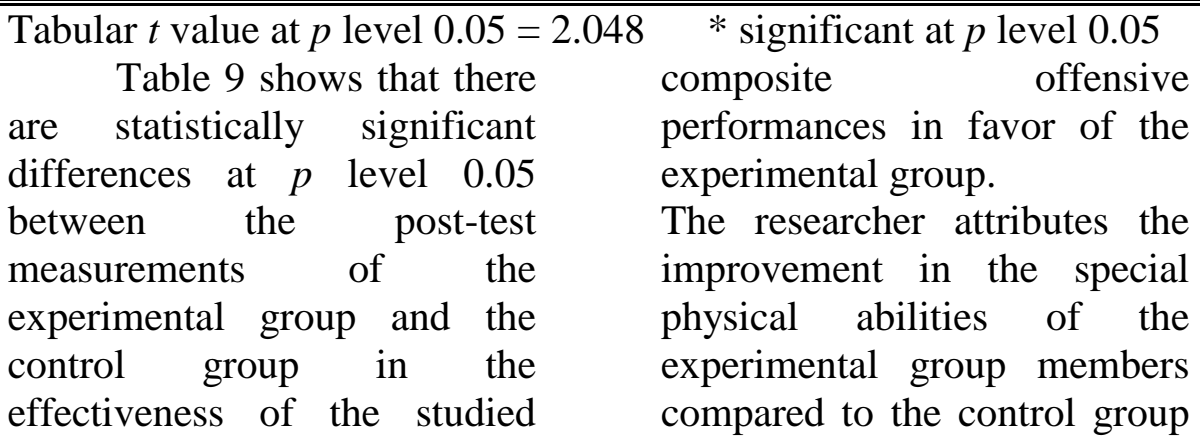 } \\
\hline \multicolumn{7}{|c|}{ Assiut Journal For Sport Science Arts } \\
\hline
\end{tabular}


members to the effectiveness of the varied training program which was used with the experimental group to develop the special physical abilities. The combination of weight and plyometric exercises used with the experimental group combined the benefits of resistance exercises and plyometrics. Additionally, the training loads were appropriately formulated, the exercises and training tools (boxes, medicine balls, dumbbells) were well selected. This resulted in the development of the arms muscular ability as represented by pushing the medicine ball to the farthest distance, and the legs muscular ability as represented by the wide jump. Moreover, using medicine balls and dumbbells in plyometric exercises of the arms and torso resulted in developing the muscular ability of the arms and shoulder girdle. Performance speed, flexibility and agility also improved due to the weights and plyometric exercises which require changing directions by twisting, turning and going up and down which improves agility. Additionally, performing some flexibility exercises during positive rest intervals resulted in improving the pelvic flexibility. Meanwhile, the control group performed only the regular physical exercises. Therefore, the experimental group outperformed the control group in the post-test measurements and the improvement rates.

The researcher also attributes the improvement in the effectiveness of the studied composite offensive performances to the fact that the program applied to the experimental group was the same as the one applied to the control group except the varied training part (weight and plyometric training) which was applied to the experimental group only as part of the training module. Additionally, the program contained physical and competitive skills exercises that resulted in differences between the experimental group's pre-test and post-test measurements in the effectiveness of some composite offensive performances. Moreover, some special physical abilities were developed naturally by the exercises related to the Kumite 
competition, both during the preparation part that contained exercises for developing the special physical abilities, or the main part that contained skills preparation exercises in the training program.

This finding is

consistent with the finding of Bassetr and Howley (2002) that using the varied training approach within the training modules was important in the athletes' special preparation period because it combined the benefits of both the resistance training (rubber bands, weight, plyometrics) and the aerobic and anaerobic endurance exercises, which helps in developing various physical abilities such as strength, ability, endurance, flexibility and speed endurance in athletes.

The findings of this study is also consistent with the findings of other studies (Al-Sayed, 2004; Gregory, 2007; Al-Safy, 2009; Abdullah, 2010; Said, et al., 2011; Mohamed, 2015; Abdul Hay, 2015) that the varied training and resistance training are effective in developing special physical abilities and the level of the skills performance compared to the traditional method.

This finding is also consistent with Shamandy and Mohib's remark (1994) that the availability of the physical fitness elements related to the performed activity help develop and improve the individual's physical and motor condition, thus contribute in achieving the requirements of the training process and the competition with the least possible effort as well as the ability to restore the normal condition quickly (Shamandy \& Mohib, 1994: 246).

Abul Nour adds (2007) that Karate is a combat sport whose players need to have many physical abilities and offensive and defensive motor skills that require a high level of ability, speed, flexibility, agility, and special endurance so that they can effectively perform the motor duties during training and competitions (Abul Nour, 2007: 4).

\section{Conclusions:}

Subject to limitations of the research sample, objectives, hypotheses, and findings, the researcher 
reached the following conclusions:

1. The varied training program has a positive effect on the special phsycal abilities (arms and legs muscular ability, pelvic flexibility, agility, punching speed, and kicking speed) of Kumite youth female players below 14 years of age.

2. The varied training program has a positive effect on the effectiveness of the studied composite offensive performances of Kumite youth female players below 14 years of age.

3. The traditional training program has a positive effect on the special physical abilities and the effectiveness of the studied composite offensive performances of Kumite youth female players below 14 years of age.

4. The varied training is more effective than traditional training in developing the special physical abilities and the effectiveness of the studied composite offensive performances of Kumite youth female players below 14 years of age.

\section{Recommendations:}

Subject to the research findings limitations and in light of its conclusions, the researcher

makes the following recommendations:

1. Varied training (weight training, plyometric training) should be used in developing the special physical abilities, as they have an effective impact on the development of the effectiveness of the composite offensive performances of Kumite youth female players below 14 years of age.

2. Stretching and flexibility exercises should be performed when varied training is applied to avoid the counter mutual effects developing strength has on flexibility.

3. Other studies should be conducted about this training approach from physiological and psychological perspectives to fully identify the effectiveness of this approach.

4. More research studies about the effect of the varied training using other training forms in Karate should e conducted.

\section{References}

1- Abdul Dayem, M.M., Saleh, M. \& Qattan, T. (1993): Physical preparation training programs and weight exercises. Cairo: Al-Ahram Press

2- Abdul Fattah, A. (1997):

Sports Training: Physiological 
basics, Cairo: Dar Al-Fikr AlArabi

\section{3- Abdul Fattah, A. \& Nasr} Eddin, A. (2003): Physiology of physical fitness, $2^{\text {nd }}$ ed., Cairo: Dar Al-Fikr Al-Arabi

4- Abdul Hay, M.A. (2015): The effectiveness of using varied training for developing special strength on the level of performing the back arch throw among youth wrestlers, M.A. Thesis, Faculty of Physical Education, Tanta University

5- Abdullah, B.H. (2010): The effectiveness of varied training on the development of some special physical abilities and the digital level of long jump female youth players in Kuwait, M.A. Thesis, Faculty of Physical Education for Girls, Zagazig University

6- Abdul Maqsoud, A. (1992): Sports training theories: Endurance training and physiology, Cairo: Free Youth Print shop

7- Abdul Maqsoud, A. (1997): Sports training theories: Strength training and physiology, Cairo: Al-Kitab Publishing Center

8- Abdul Qader, A.M. \& Tantawy, S.A. (2004): Constructing a battery of physical tests of Kata players in Karate, Scientific Journal of Physical Education, no. 3, Faculty of Physical Education for Boys, Helwan University

9- Abul Lif, M.A. (2002): The effect of developing anaerobic ability on some special physical features and the Kata performance level of 12-14year-old Karate youth players, M.A. Thesis, Faculty of Physical Education in Port Said, Suez Canal University 10- Abul Nour, M.S. (2007): The effect of a training program for developing some special physical components on the Kata performance of Karate players, Ph.D. Thesis, Faculty of Physical Education for Boys, Zagazig University

11- Abul Nour, M.S. (2002): The effectiveness of developing some composite offensive skills on match results of Karate players, M.A. Thesis, Faculty of Physical Education for Boys, Zagazig University

12- Ahmed, A.I. (2008): The effect of specific exercises program on the effectiveness of performing sweep techniques followed by punching and kicking among Karate youth players, M.A. Thesis, Faculty 
of Physical Education, Mansoura University

13- Ahmed, H.A. (2008): The effect of developing mental imagery on improving the performance time of some composite offensive skills among Karate youth players, M.A. Thesis, Faculty of Physical Education for Girls, Alexandria University

14- Al-Awady, S.A. (1989): Analyzing some offensive waves skills in the international level as a basis for developing a training program for these skills, Ph.D. Thesis, Faculty of Physical Education, Menia University

15- Al-Awady, S.A. \& Labib, O.M. (2004): Offence rules, Karate series, Kumite set Al-Ajamy, S.M. (2007): The effect of a training program using specific exercises on attaining the black belt $\left(1^{\text {st }}\right.$ dan) requirements among Karate youth players, M.A. Thesis, Faculty of Physical Education, Mansoura University

16- Al-Beshihy, M.R. (2005): The effect of a training program of skills and tactical characteristics according to the international level matches strategy on the performance level and results of Karate players, Ph.D. Thesis, Faculty of Physical Education for Boys, Helwan University

17- Al-Ghamrawy, A.M. (2007): A proposed training program for developing some composite offensive skills among 11-13-year-old Karate players, Ph.D. Thesis, Faculty of Physical Education for Boys, Alexandria University

18- Allawy, M.H. \& Radwan, M.N. (2001): Motor performance tests, $5^{\text {th }}$ ed. Cairo: Dar Al-Fikr Al-Arabi

19- Al-Masry, T.K. (2013): The effectiveness of using counter tactical approaches of left-handed Kumite player on the level of performance of Karate youth players, M.A. Thesis, Faculty of Physical Education, Tanta University

20- Al-Nemr, A. \& AlKhatib, N. (1996): Weight training, designing strength programs, and planning the training season. Cairo: AlKitab publishing center

21- Al-Safy, M.S. (2009): The effect of using varied training on some physical and skills variables of basketball players, M.A. Thesis, Faculty of Physical Education, Menia University 
22- Al-Sayed, E.I. (2004): The effect of varied training using weights and plyometrics on some special physical abilities and the digital level of long jump players, Ph.D. Thesis, Faculty of Physical Education, Tanta University

23- Al-Sokkary, K. \& Beriqa, M.G. (2001): Integrated training series, Part I, Alexandria: Monshaat AlMaarif

24- Hafez, S.M. (2010):

Mental toughness and sensorymotor perception as an introduction to develop the performance of composite offensive skills and selfesteem, among Karate youth players, M.A. Thesis, Faculty of Physical Education for Girls, Helwan University

25- Hassan, Z.M. (1998): Plyometric training: Its meaning, development and use with youth players, Al-Fikr AlArabi physical education and sports series, Cairo: Dar AlFikr Al-Arabi

26- Hassanein, M.S. (2001): Evaluation and Measurement in Physical Education and Sport, $4^{\text {th }}$ ed., Part I, Cairo: Dar Al-Fikr Al-Arabi

\section{7- Hassanein, M.S. \& Kesra,}

A. (1998): Encyclopedia of applied sports training, Cairo: Al-Kitab publishing center

28- Hussein, S.S. (2001): Effectiveness of exercises with different resistances in water medium on the level of skills performance among Karate players (first degree), Journal of Comprehensive Physical Education Researches, Faculty of Physical Education for Girls, Zagazig University

29- Ibrahim, A.M. (1995): Principles of planning educational and training programs in Karate, Alexandria: Monshaat AlMaarif

30- Ibrahim, A.M. (1991): Developing some special physical abilities and its effect on the level of basic punches and kicks among 10-12-yearold Karate youth players, Ph.D. Thesis, Faculty of Physical Education for Boys, Alexandria University 
31- Ibrahim, A.M. \& AlBesaty, A.A. (1995): The effect of directing training jobs according to the vital rhythm pattern on the values of some functional indicators and the level of skills performance of the international movement sequence among Karate players, Scientific Journal (Theories and Practices), Faculty of Physical Education for Boys, Alexandria University

32- Ismail, M.A. (1998): Muscle power training and weight programs for children, Alexandria: Monshat AlMaarif

33- Jamal, M. (2013): The effect of varied training using weights and plyometrics on the development of some physical features and improving the jump shot among 13-15- yearold handball players, Theories and Practices Journal, no. 77, part I, Faculty of Physical Education for Boys, Alexandria University

34- Mahmoud, M.A. (1997): Basic principles of freestyle and Greco-Roman wrestling for amateurs, Faculty of Physical Education, Mansoura University

35- Metwally, M.A. (2013):

The effect of using mastery learning on the performance of some offensive combinations among Kumite youth players in Karate, Ph.D. Thesis, Faculty of Physical Education for Boys, Zagazig University

36- Mohamed, M.A. (2015): The effect of varied training on the effectiveness of offensive skills among first degree Karate players, M.A. Thesis, Faculty of Physical Education, Mansoura University

37- Said, S.M., Mohamed, N.Q. \& Hassan, M.M. (2011): The effect of varied training on the development of legs muscle power in basketball players, Journal of College of Basic Education Researches, vol. 11, no. 2, Mousul University, Iraq 38- Samy, M.H. (2007): A study of some anthropometric, physical and psychological measurements for selecting youth players in Karate, M.A. 
Thesis, Faculty of Physical Education, Mansoura University

39- Shamandy, W.A. (2002): Preparing the Karate player for contests: Theory and practice. Cairo: Khattab Print Shop 40- Shamandy, W.A. \& Mohib, H. (1994): Studying some biological variables of high level Karate players, Scientific Journal of Physical Education and Sport, no. 21 Faculty of Physical Education for Boys, Helwan University 41- Shehata, M.I. (1997): Strength exercises and weights, Cairo: Dar Al-Fikr Al-Arabi
42- Tantawy, S.A. \& Abdul Qader, A.M. (2004): The effect of competitive exercises with weights on some physical abilities and the level of skills performance in Karate, Scientific Journal of Research and Studies, no. 8, Faculty of Physical Education in Port Said, Suez Canal University 43- Zayed, S.S. (2000): The effect of a weight and plyometric training program on the growth rates of the muscular ability of Karate youth players before puberty, M.A. Thesis, Faculty of Physical Education for Boys, Helwan University 